\title{
Data report: anisotropy of magnetic susceptibility measurement on samples from Sites C0004, C0006, C0007, and C0008, IODP Expedition $316^{1}$
}

\author{
Yujin Kitamura, ${ }^{2}$ Xixi Zhao, ${ }^{3,4}$ and Toshiya Kanamatsu ${ }^{5}$
}

\section{Chapter contents}

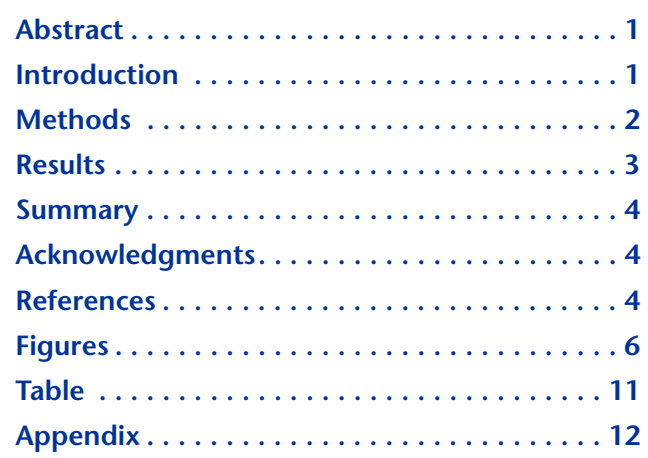

'Kitamura, Y., Zhao, X., and Kanamatsu, T., 2015. Data report: anisotropy of magnetic susceptibility measurement on samples from Sites C0004, C0006, C0007, and C0008, IODP Expedition 316. In Kinoshita, M., Tobin, H., Ashi, J., Kimura, G., Lallemant, S., Screaton, E.J., Curewitz, D., Masago, H., Moe, K.T., and the Expedition 314/315/316 Scientists, Proc. IODP, 314/315/316: Washington, DC (Integrated Ocean Drilling Program

Management International, Inc.).

doi:10.2204/iodp.proc.314315316.222.2015

2Department of Earth and Environmental Sciences, Graduate School of Science and Technology, Kagoshima University, 1-21-35 Korimoro, Kagoshima 890-0065, Japan.

yujin@sci.kagoshima-u.ac.jp

${ }^{3}$ State Key Laboratory of Marine Geology, Tongji University, 1239 Siping Road, Shanghai 200092, China.

${ }^{4}$ Department of Earth and Planetary Sciences, University of California Santa Cruz, 1156 High Street, Santa Cruz CA 95064, USA.

${ }^{5}$ R\&D Center for Earthquake and Tsunami, Japan Agency for Marine-Earth Science and Technology, 2-15 Natsushima-cho, Yokosuka-city, Kanagawa 237-0061, Japan.

\section{Abstract}

We carried out anisotropy of magnetic susceptibility (AMS) measurements on samples from Integrated Ocean Drilling Program Sites C0004, C0006, C0007, and C0008 recovered during Expedition 316 to examine their magnetic fabrics. Magnetic susceptibility, $\mathrm{Km}$, varied with lithology at each drilling site. Nondeformed sediments should show a positive shape parameter, $T$, indicating retention of their initial state of deposition and compaction. At Site C0004, the shape parameter reveals a scattered plot in the units of the megasplay fault zone and mass wasting deposits. A similar trend was observed in Unit I at Site C0007 in the prism toe, which also consists of mass wasting deposits. In contrast, the mass transport complex at Site C0008 has an enhanced compaction fabric. Despite the existence of many thrusts, the sediments at Sites C0006 and C0007 display a trend associated with compaction, with a drastic change in the orientation of magnetic fabric at the bottom of the holes. As a general implication, the sediments in this area obtained rather flattened fabrics at first and kept them, unless they were affected by later mechanical deformation. Due to tectonic disturbances in mass wasting deposits and the megasplay fault, deformed sediments/rocks are characterized by dispersed shape parameter values. Our results suggest that the AMS is potent to characterize mechanically disordered units in core samples and provides useful information for the onset of seismogenic behavior and locking of subduction thrusts.

\section{Introduction}

The physical properties of material in the accretionary prism and at tectonic subducting margin tectonic boundaries are fundamental to understanding the dynamic processes of plate subduction. In terms of large earthquakes in subduction zones, two possible major plate boundaries (approximately horizontal décollement extending to the trench and its branching megasplay fault, which are best exampled in the Nankai Trough) are the most important tectonic features. Since magnetic fabric analysis can provide reliable and important information about the formation and subsequent tectonic history of rock units, we aim to examine variations of sedimentary magnetic fabric characteristics across both the megasplay fault and the frontal thrust in the Nankai Trough, Ja- 
pan, using samples from Integrated Ocean Drilling Program (IODP) Expedition 316.

Documenting the state of stress and strain in the accretionary prism is crucial for understanding the faulting process in a subduction zone. The triggers for catastrophic faulting at the plate boundary could be due to thermal condition, fluid pressure, lithification, and wedge shape. In order to constrain this problem, it is important to describe the observable stress and strain at the plate boundary. However, the large-scale structures within an accretionary prism and their links to the seismogenic process are still vague. For any field related to subduction zone process, information about the present status of strain and/or stress is fundamental. Difficulties often arise regarding the limited volume of material at any given depth when attempting to conduct structural and sedimentological analyses of marine sediments from drilled cores. The use of anisotropy of magnetic susceptibility (AMS) provides a quick and nondestructive analysis for small samples that enables us to grasp an overview of structure in drilled cores with systematic sampling. It has been demonstrated by previous ocean drilling expeditions that AMS analysis plays a key role in the investigation and understanding of deformation zones, for example, during Ocean Drilling Program (ODP) Legs 131, 156, 170, and 190 and the IODP NanTroSEIZE expeditions (Owens, 1993; Housen et al., 1996; Housen and Kanamatsu, 2003; Ujiie et al., 2003; Kitamura et al., 2010, 2014; Kanamatsu et al., 2012, 2014; Novak et al., 2014). In this report, we present the results of our AMS study of samples taken during IODP Expedition 316 at Sites C0004, C0006, C0007, and C0008 (Fig. F1). Intense sampling throughout the drilled cores provides an excellent overview of sediment deformation within and across an active subduction margin.

\section{Methods}

AMS measurements were made on a total of 899 samples $\left(\sim 7 \mathrm{~cm}^{3}\right.$ volume) from Sites C0004 $(n=209)$, C0006 $(n=255), \operatorname{C0007}(n=101)$, and C0008 $(n=$ 334). Samples were collected at regular intervals from every possible section and were measured with the AGICO KLY 4S Kappabridge installed at the Institute for Research on Earth Evolution, Japan Agency for Marine-Earth Science and Technology.

Magnetic susceptibility is a proportionality between the intensity of the induced magnetic field and that of the applied magnetic field. AMS represents the geometric alignment and intensity of mineral fabrics as a magnetic ellipsoid, which is commonly interpreted to reflect the strain ellipsoid (e.g., Borradaile and Alford, 1988). The magnetic susceptibility ellip- soids are expressed with the principal susceptibility axes $(\mathrm{K} 1>\mathrm{K} 2>\mathrm{K} 3)$. The minimum axis $\mathrm{K} 3$ is widely regarded as the orientation of maximum shortening (e.g., Borradaile, 1991). A sensitive response of unconsolidated sediments in accretionary prisms to applied stress has been detected with AMS studies (e.g., Byrne et al., 1993; Owens, 1993), which shows the $\mathrm{K} 3$ axis oriented toward the maximum shortening strain.

All the raw data listed in Table T1 have been measured with a KLY 4S Kappabridge, and all the derived parameters are described in the "Appendix." Here we present the following parameters derived from the principal susceptibility axes for discussion: the bulk magnetic susceptibility $K m$, the lineation parameter $L(\mathrm{~K} 1 / \mathrm{K} 2)$ and the flattening parameter $F$ (K2/K3), the anisotropy degree $\left(P^{\prime}\right)$ and the shape parameter $(T)$, and the inclination of $\mathrm{K} 1$ and $\mathrm{K} 3 . P^{\prime}$ and the $T$ are, conceptually, amended expressions in a polar coordinate system proposed by Jelinek (1981) out of traditional lineation versus a foliation $(L-F)$ diagram (Flinn diagram) commonly used for structural geology.

$K m$ reflects the amount of magnetically susceptible components in the specimen and thus reflects lithology and/or mineralogy. $L-F$ and $P^{\prime}-T$ are pairs of factors that show the shape of magnetic ellipsoids but are different in their main focus. $L$ and $F$ indicate the intensity of the shape components, lineation and flattening, respectively. Given both $L$ and $F$, we know the shape of the ellipsoid. $T$ provides the shape information (oblate if $0<T<1$ and prolate if $-1<T$ $<0$ ), where the intensity of distortion compared to the true sphere is presented by $P^{\prime}$. Therefore, $P^{\prime}-T$ data are useful for discussing the general shape of the magnetic ellipsoid while $L-F$ data are most useful for highlighting the lineation or flattening components.

For normally deposited and compacted marine sediments, it is expected that $P^{\prime}$ shows a gradual increase with depth in association with the reduction of porosity, and $T$ is approximately random in shallow sediments and shifts toward oblate values with depth (Kitamura et al., 2010). This compaction trend is seen as a stable $L$ and increasing $F$ with depth. A vertical $\mathrm{K} 3$ axis is expected for gravitational compaction (e.g., Kanamatsu et al., 2012).

We selected clayey samples for the AMS measurements. The magnetic properties of the samples from this expedition have been reported by Zhao and Kitamura (2011) in a study documenting that the main magnetic component is paramagnetic minerals with a diamagnetic effect and multidomain or pseudosingle domain size components. Magnetic susceptibility is carried by a comparable amount of the magnetitetitanomagnetite series mineral and clay minerals (Ki- 
tamura et al., 2010; Zhao and Kitamura, 2011). The chemical effects that could change magnetic properties appear to be minor, as there are no signs of such effects from previous results in this area (Kitamura et al., 2010; Zhao and Kitamura, 2011).

\section{Results}

Results of AMS measurements are shown in a series of plots against depth (Figs. F2, F3, F4, F5). Here we present results in two focus areas, the megasplay fault and the frontal thrust zone.

\section{Megasplay fault area}

At Site C0004, the results show variation in each lithostratigraphic unit (Fig. F2). The most significant feature here is that the shape parameter $T$ shows peculiarly scattered plots in Subunit IIA and Unit III that correspond to mass wasting deposits and a faultbounded package, respectively. In Unit I, Subunit IIB and Unit IV, positive $T$ appears relatively dominant. The degree of anisotropy $P^{\prime}$ first increases (roughly from 1.01 to 1.04) downward in Unit I and is distributed within the same range with no particular trend in Subunit IIA. The data from Subunit IIB, in which the core recovery was rather poor, show that the degree of anisotropy has relatively low values (from 1.00 to 1.02) in general, whereas some samples show remarkably high values (from 1.08 to 1.13). The AMS parameters from Unit III are nearly equivalent to the majority of results from Subunit IIB, and grade into an increase in Unit IV.

The inclination of $\mathrm{K} 3$ axes is very steep in Unit I $\left(60^{\circ}-90^{\circ}\right)$ and Unit IIA $\left(50^{\circ}-80^{\circ}\right)$, whereas at their boundary, which forms an unconformity, the inclination is quite gentle $\left(10^{\circ}-40^{\circ}\right)$. The data below Unit IIA are dispersed. K3 inclination is no more than $75^{\circ}$ in Unit III and ranges between $60^{\circ}$ and $90^{\circ}$ in Unit IV.

At Site C0008, Holes C0008A and C0008C showed trends that were similar to each other (i.e., $K m, F$, and $P^{\prime}$ start increasing with depth from the middle of Subunit IA, low $L$, positive $T$, and stable axes inclinations) (Fig. F5). In Hole C0008A, $P^{\prime}$ is stable ( 1.02) in the uppermost $150 \mathrm{~m}$ of sediments and shifts to a much higher value (up to $>1.10$ ) deeper in the core. $T$ has a positive value, and the inclination of the K3 axes is steep $\left(60^{\circ}-90^{\circ}\right)$ throughout the hole. In the uppermost $16 \mathrm{~m}$ of sediments, inclination of the $\mathrm{K} 3$ axes is highly variable, and the biostratigraphic data suggest a discontinuity lurks somewhere between Samples 316-C0008A-1H-CC (6.805 meters core depth below seafloor [m CSF] $)$ and 3H-CC (25.595 m CSF) (see the "Site C0008" chapter [Expedition 316 Scientists, 2009d]). Sediments from Subunit IB, which is described as a mass transport complex (see the "Site C0008" chapter [Expedition 316 Scientists, 2009d]), show signs of compaction: porosity reduction with depth, high $F$, high $P^{\prime}$, positive $T$, and vertical K3. The higher value of Km in Subunit IB may enhance this distinct shape information. In Hole C0008C, the parameters behave synchronously with Hole C0008A with the exception of a seamless increment in the degree of anisotropy. The unstabilized inclination of the $\mathrm{K} 3$ axes in the uppermost $9 \mathrm{~m}$ of Hole C0008C also corresponds to a reported discontinuity between Samples 316-C0008C-1H-CC (5.420 $\mathrm{m}$ CSF) and 3H-CC (25.345 m CSF).

\section{Frontal thrust area}

The results and initial interpretations of the samples from the frontal thrust area in the accretionary prism toe are partly published in Kitamura et al. (2010), on which the following description is based.

At Site C0006, $P^{\prime}$ starts low (1.01-1.05) and increases (maximum $=1.15)$ with depth (Fig. F3). The majority of the inclinations of $\mathrm{K} 3$ axes are steep. With respect to positive $T$, the magnetic ellipsoid generally tends to become more flattened as is buried more deeply, similar to Site C0008 nondeformed slope basin deposits. However, several different features reflect the distinct structural setting in this site.

For example, there is a clear gap in terms of $P^{\prime}$ and the inclination of the K3 axes at $\sim 400 \mathrm{~m}$ CSF. A major change in the trend of $P^{\prime}$ occurs in Subunit IID (391.33 m CSF) where there is a meaningful drop of $\sim 0.9$. $T$ shows positive values except in the two uppermost units, Unit I and Subunit IIA. The inclinations of $\mathrm{K} 3$ axes are also scattered in Unit I and Subunit IIA, but below that the data can be classified into a steep portion (from $\sim 80$ to $440 \mathrm{~m} \mathrm{CSF}$ ) and a gentle portion (below $440 \mathrm{~m} \mathrm{CSF}$ ). With more meticulous inspection, a stepwise decrease of inclination is observed at $405 \mathrm{~m} \mathrm{CSF}$, where the large degree of anisotropy $\left(P^{\prime}>1.1\right)$ decreases to lower values $\left(P^{\prime}<\right.$ 1.1).

Technical difficulties in drilling at Site $\mathrm{C0007}$ led to poor recovery in the middle of the hole and below the frontal thrust (Fig. F4). Despite incomplete recovery, the results are generally consistent with the adjacent Site C0006 (which is $~ 800 \mathrm{~m}$ landward). In the uppermost $100 \mathrm{~m}$ of Site C0007, $T$ and the inclination of K3 axes are not consistent; however, they do vary less than those of Site C0006. $T$ varies between -0.86 and 0.96 at Site C0006, whereas the data from Site C0007 occupy a smaller range, from -0.42 to 0.81 . The inclinations of $\mathrm{K} 3$ axes are gentle $\left(<60^{\circ}\right)$ rather than scattered in Unit I of Site C0007, and the sandy unit below does not show values as scattered as those found at Site C0006. In Unit III, $T$ values are 
concentrated around zero, which indicates that the magnetic ellipsoid is either spherical (low $P^{\prime}$ value) or scalene (high $P^{\prime}$ value) (e.g., Jelinek, 1981; Borradaile, 1991).

\section{Summary}

The sediments recovered during Expedition 316 obtained flattened fabrics at their initial stage of deposition and partly overprinted when they were affected by later mechanical deformation. The shape parameter showed a scattered plot in the section of the megasplay fault (Site C0004) and mass wasting deposits (Sites C0004 and C0007). In contrast, the mass transport complex at Site C0008 has an enhanced compaction fabric. Despite many thrusts, the sediments of Sites C0006 and C0007 reveal a trend associated with compaction, with a drastic change in the orientation of magnetic fabric at the bottom of the holes.

Our results reflect the acquisition of compaction fabric in sedimentary materials during burial. However, anomalies in this general (and expected) trend provide information about the sediment deformation or diagenesis. In the lower part of the prism toe, at Sites C0006 and C0007, AMS fabrics occasionally rotate almost $90^{\circ}$, interpreted by Kitamura et al. (2010) as indication of horizontal compression. Later discussions raised the question of whether this horizontal compression is apparent, and this issue is under examination. The sedimentary character of the mass transport complex at Site C0008 was compared against another mass transport complex from neighboring Site C0018 in a previous paper (Kitamura et al., 2014). Results from Site C0004 showed complex magnetic fabrics across the megasplay fault. Thorough comparison between lithology, deformation, physical properties and magnetic fabric is necessary to document the magnetic fabric change associated with large-scale thrusting, which contributes to understand surface process of subduction zone and to provide better view of the evolution of accretionary prism.

\section{Acknowledgments}

We thank reviewer Dr. B. Novak for the constructive comments and Dr. K. Tsuchida (Marine Works Japan Co. Ltd.) for providing technical support with regard to the AMS measurements. We are grateful to the Expedition 316 Scientists and, especially, the technicians and crew for their magnificent onboard work. We thank the co-chief scientists, Drs. G. Kimura and E. Screaton, for leading the successful expedition and the Expedition Project Manager, Dr. D. Curewitz, for providing excellent support and management. This research used samples and/or data provided by the Integrated Ocean Drilling Program (IODP). This work was partially supported by KAKENHI 19GS0211 and 21107001 and by U.S. National Science Foundation Grant EAR-1250444.

\section{References}

Borradaile, G.J., 1991. Correlation of strain with anisotropy of magnetic susceptibility (AMS). Pure Appl. Geophys., 135(1):15-29. doi:10.1007/BF00877006

Borradaile, G.J., and Alford, C., 1988. Experimental shear zones and magnetic fabrics. J. Struct. Geol., 10(8):895904. doi:10.1016/0191-8141(88)90102-2

Byrne, T., Brückmann, W., Owens, W., Lallemant, S., and Maltman, A., 1993. Structural synthesis: correlation of structural fabrics, velocity anisotropy, and magnetic susceptibility data. In Hill, I.A., Taira, A., Firth, J.V., et al., Proc. ODP, Sci. Results, 131: College Station, TX (Ocean Drilling Program), 365-378. doi:10.2973/ odp.proc.sr.131.142.1993

Expedition 316 Scientists, 2009a. Expedition 316 Site C0004. In Kinoshita, M., Tobin, H., Ashi, J., Kimura, G., Lallemant, S., Screaton, E.J., Curewitz, D., Masago, H., Moe, K.T., and the Expedition 314/315/316 Scientists, Proc. IODP, 314/315/316: Washington, DC (Integrated Ocean Drilling Program Management International, Inc.). doi:10.2204/iodp.proc.314315316.133.2009

Expedition 316 Scientists, 2009b. Expedition 316 Site C0006. In Kinoshita, M., Tobin, H., Ashi, J., Kimura, G., Lallemant, S., Screaton, E.J., Curewitz, D., Masago, H., Moe, K.T., and the Expedition 314/315/316 Scientists, Proc. IODP, 314/315/316: Washington, DC (Integrated Ocean Drilling Program Management International, Inc.). doi:10.2204/iodp.proc.314315316.134.2009

Expedition 316 Scientists, 2009c. Expedition 316 Site C0007. In Kinoshita, M., Tobin, H., Ashi, J., Kimura, G., Lallemant, S., Screaton, E.J., Curewitz, D., Masago, H., Moe, K.T., and the Expedition 314/315/316 Scientists, Proc. IODP, 314/315/316: Washington, DC (Integrated Ocean Drilling Program Management International, Inc.). doi:10.2204/iodp.proc.314315316.135.2009

Expedition 316 Scientists, 2009d. Expedition 316 Site C0008. In Kinoshita, M., Tobin, H., Ashi, J., Kimura, G. Lallemant, S., Screaton, E.J., Curewitz, D., Masago, H., Moe, K.T., and the Expedition 314/315/316 Scientists, Proc. IODP, 314/315/316: Washington, DC (Integrated Ocean Drilling Program Management International, Inc.). doi:10.2204/iodp.proc.314315316.136.2009

Housen, B.A., and Kanamatsu, T., 2003. Magnetic fabrics from the Costa Rica margin: sediment deformation during the initial dewatering and underplating process. Earth Planet. Sci. Lett., 206(1-2):215-228. doi:10.1016/ S0012-821X(02)01076-2

Housen, B.A., Tobin, H.J., Labaume, P., Leitch, E.C., Maltman, A.J., and Ocean Drilling Program Leg 156 Shipboard Science Party, 1996. Strain decoupling across the décollement of the Barbados accretionary prism. Geol- 
ogy, 24(2):127-130. doi:10.1130/

0091-7613(1996)024<0127:SDATDO>2.3.CO;2

Jelinek, V., 1981. Characterization of the magnetic fabric of rocks. Tectonophysics, 79(3-4):T63-T67. doi:10.1016/ 0040-1951(81)90110-4

Kanamatsu, T., Kawamura, K., Strasser, M., Novak, B., and Kitamura, Y., 2014. Flow dynamics of Nankai Trough submarine landslide inferred from internal deformation using magnetic fabric. Geochem., Geophys., Geosyst., 15(10):4079-4092. doi:10.1002/2014GC005409

Kanamatsu, T., Parés, J.M., and Kitamura, Y., 2012. Pliocene shortening direction in Nankai Trough off Kumano, southwest Japan, Sites IODP C0001 and C0002, Expedition 315: anisotropy of magnetic susceptibility analysis for paleostress. Geochem., Geophys., Geosyst., 13(1). doi:10.1029/2011GC003782

Kitamura, Y., Kanamatsu, T., and Zhao, X., 2010. Structural evolution in accretionary prism toe revealed by magnetic fabric analysis from IODP NanTroSEIZE Expedition 316. Earth Planet. Sci. Lett., 292(1-2):221-230. doi:10.1016/j.epsl.2010.01.040

Kitamura, Y., Strasser, M., Novak, B., Kanamatsu, T., Kawamura, K., and Zhao, X., 2014. Characteristics of magnetic fabrics in mass transport deposits in the Nanka Trough trench slope, Japan. In Krastel, S., Behrmann, J.-H., Völker, D., Stipp, M., Berndt, C., Urgeles, R., Chaytor, J., Huhn, K., Strasser, M., and Harbitz, C.B. (Eds.), Submarine Mass Movements and Their Consequences. Adv. Nat. Technol. Hazards Res., 37:649-658. doi:10.1007/978-3-319-00972-8_58
Novak, B., Housen, B., Kitamura, Y., Kanamatsu, T., and Kawamura, K., 2014. Magnetic fabric analyses as a method for determining sediment transport and deposition in deep sea sediments. Mar. Geol., 356:19-30. doi:10.1016/j.margeo.2013.12.001

Owens, W.H., 1993. Magnetic fabric studies of samples from Hole 808C, Nankai Trough. In Hill, I.A., Taira, A., Firth, J.V., et al., Proc. ODP, Sci. Results, 131: College Station, TX (Ocean Drilling Program), 301-310. doi:10.2973/odp.proc.sr.131.130.1993

Ujiie, K., Hisamitsu, T., and Taira, A., 2003. Deformation and fluid pressure variation during initiation and evolution of the plate boundary décollement zone in the Nankai accretionary prism. J. Geophys. Res., 108:(B8):2398. doi:10.1029/2002JB002314

Zhao, X., and Kitamura, Y., 2011. Data report: magnetic property studies of sediments and rocks from IODP Expedition 316. In Kinoshita, M., Tobin, H., Ashi, J., Kimura, G., Lallement, S., Screaton, E.J., Curewitz, D., Masago, H., Moe, K.T., and the Expedition 314/315/316 Scientists, Proc. IODP, 314/315/316: Washington, DC (Integrated Ocean Drilling Program Management International, Inc.). doi:10.2204/ iodp.proc.314315316.215.2011

Initial receipt: 27 June 2013

Acceptance: 19 April 2015

Publication: 6 July 2015

MS 314315316-222 
Figure F1. Map of Nankai Trough area, showing location of Sites C0004-C0008 (white circles). Large square and star = rupture zone and epicenter of 1944 Tonankai earthquake. $\mathrm{EP}=$ Eurasian plate, NAP = North American plate, $\mathrm{PP}=$ Pacific plate, $\mathrm{PSP}=$ Philippine Sea plate.

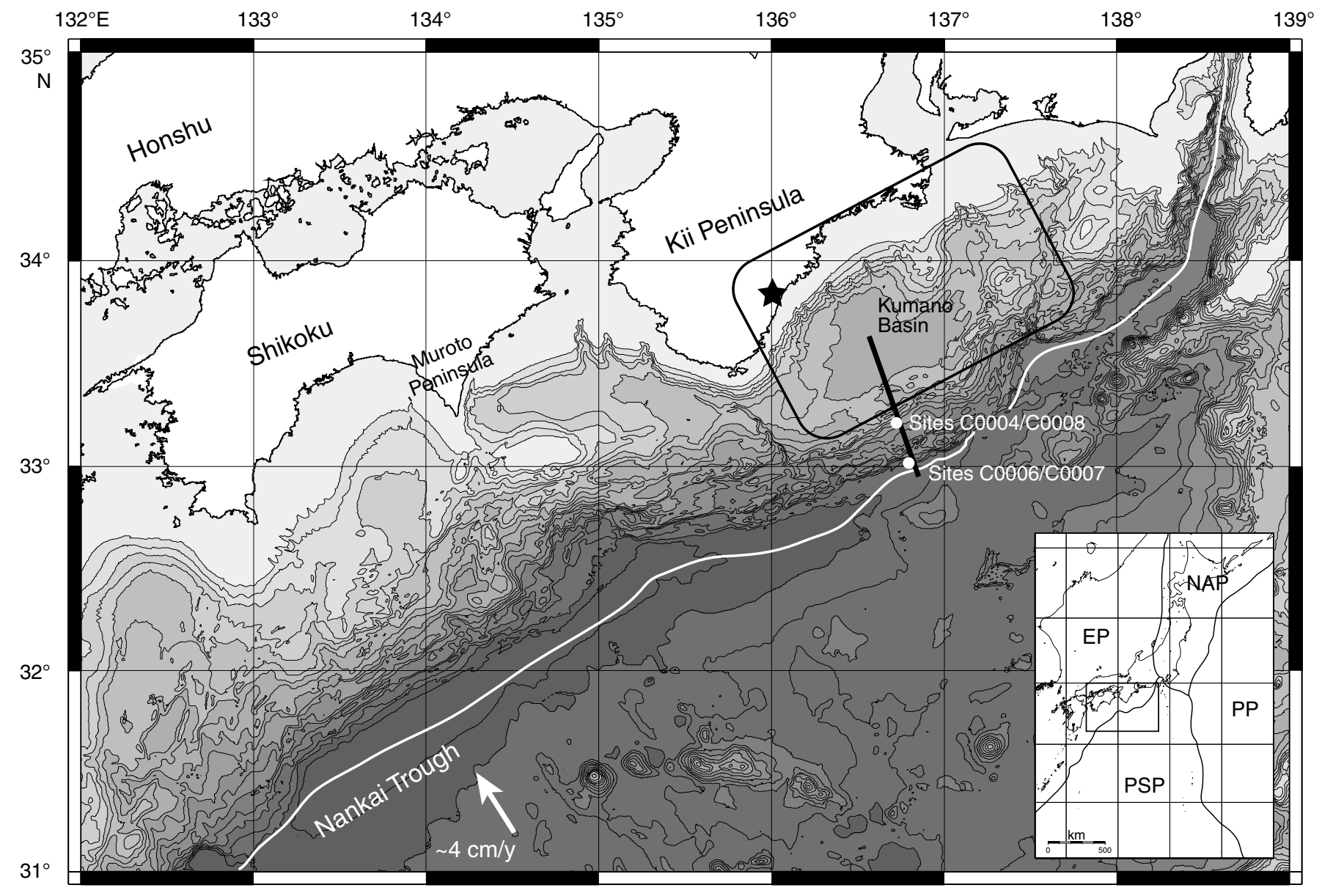


Figure F2. AMS parameters plotted against depth for samples from Site C0004. Porosity and bedding dip data are from onboard measurement (see the "Site C0004" chapter [Expedition 316 Scientists, 2009a]). Km = bulk magnetic susceptibility, $L=$ lineation parameter $(\mathrm{K} 1 / \mathrm{K} 3), F=$ flattening parameter $(\mathrm{K} 2 / \mathrm{K} 3), P^{\prime}=$ anisotropy degree, $T$ = shape parameter, incl. = inclination.

\section{Site C0004}
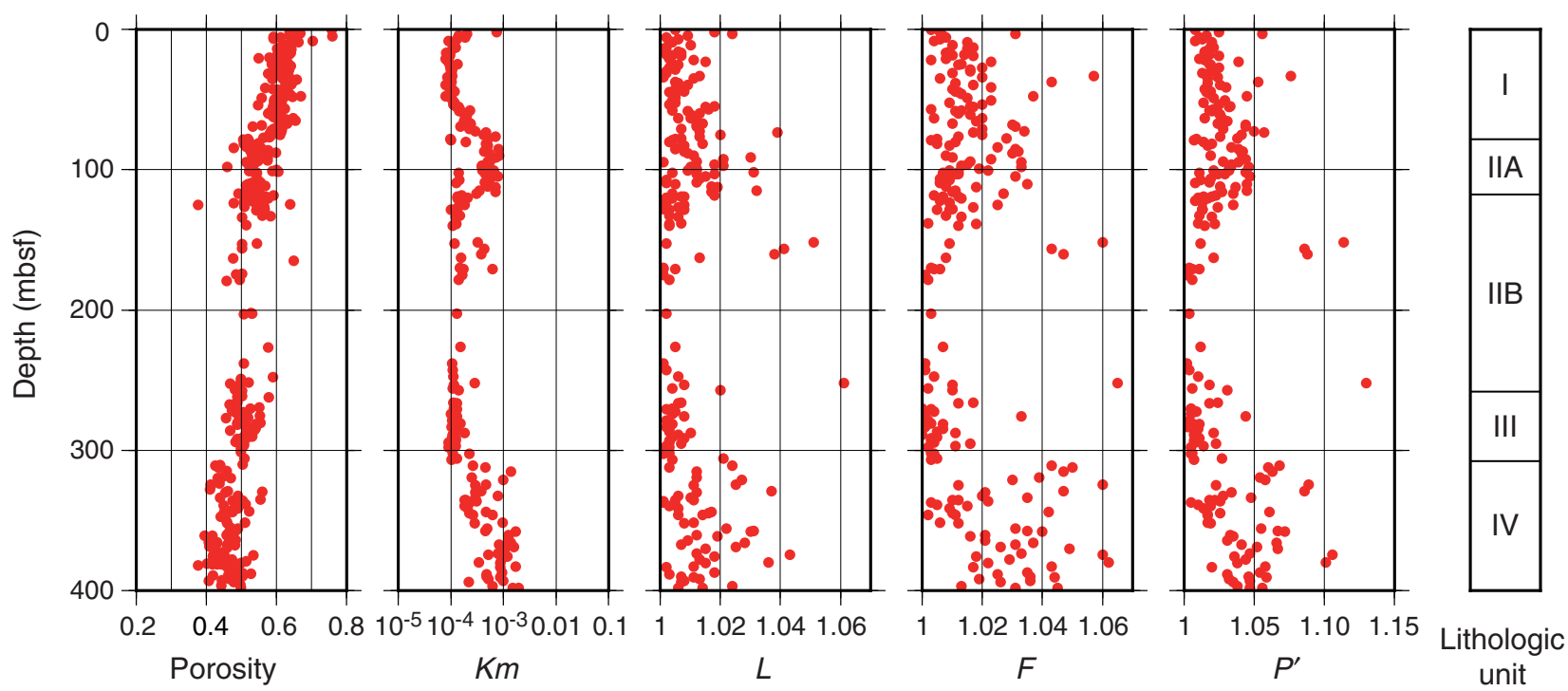

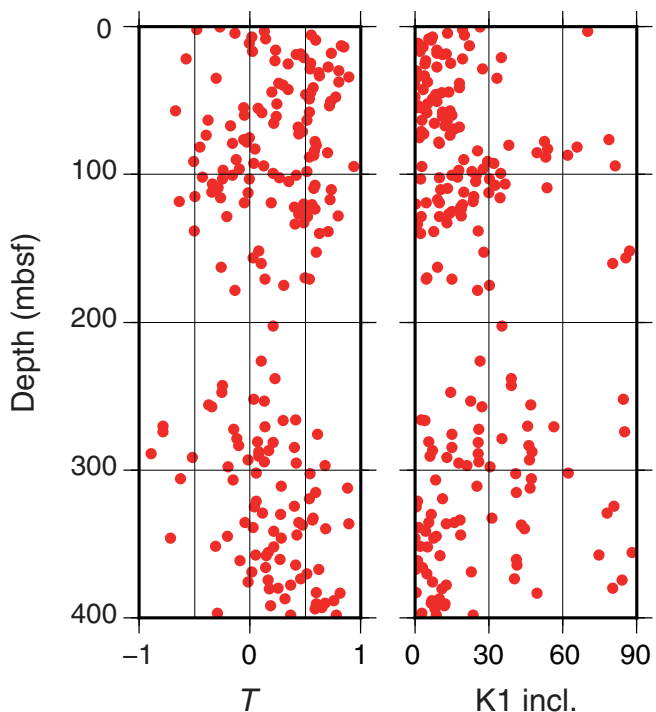

$\left.{ }^{\circ}\right)$

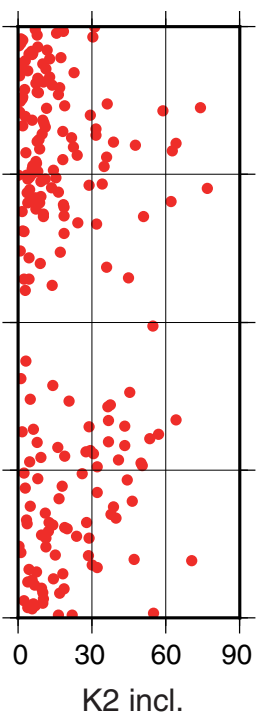

$\left({ }^{\circ}\right)$

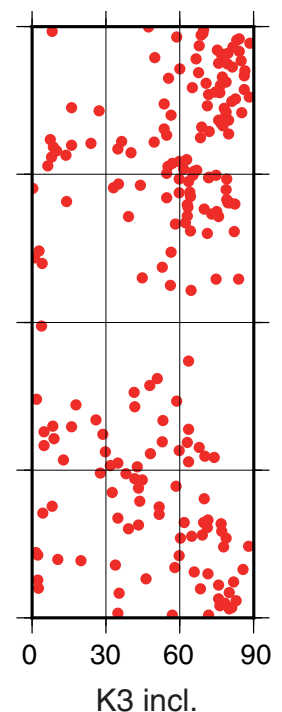

( $)$

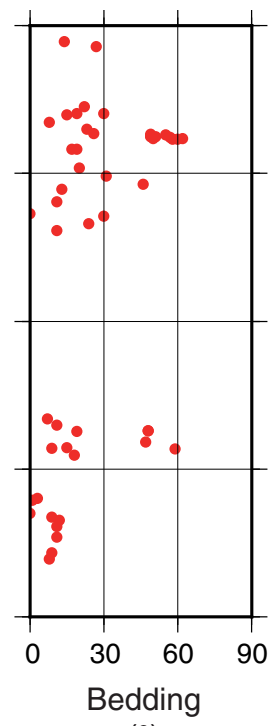

$\left({ }^{\circ}\right)$

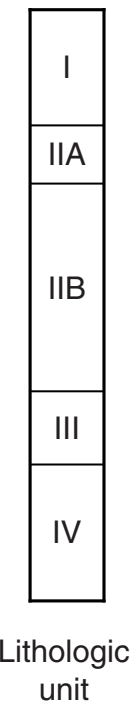

unit 
Figure F3. AMS parameters plotted against depth for samples from Site C0006. Porosity and bedding dip data are from onboard measurement (see the "Site C0006" chapter [Expedition 316 Scientists, 2009b]). Km = bulk magnetic susceptibility, $L=$ lineation parameter $(\mathrm{K} 1 / \mathrm{K} 3), F=$ flattening parameter $(\mathrm{K} 2 / \mathrm{K} 3), P^{\prime}=$ anisotropy degree, $T$ = shape parameter, incl. = inclination.

Site C0006
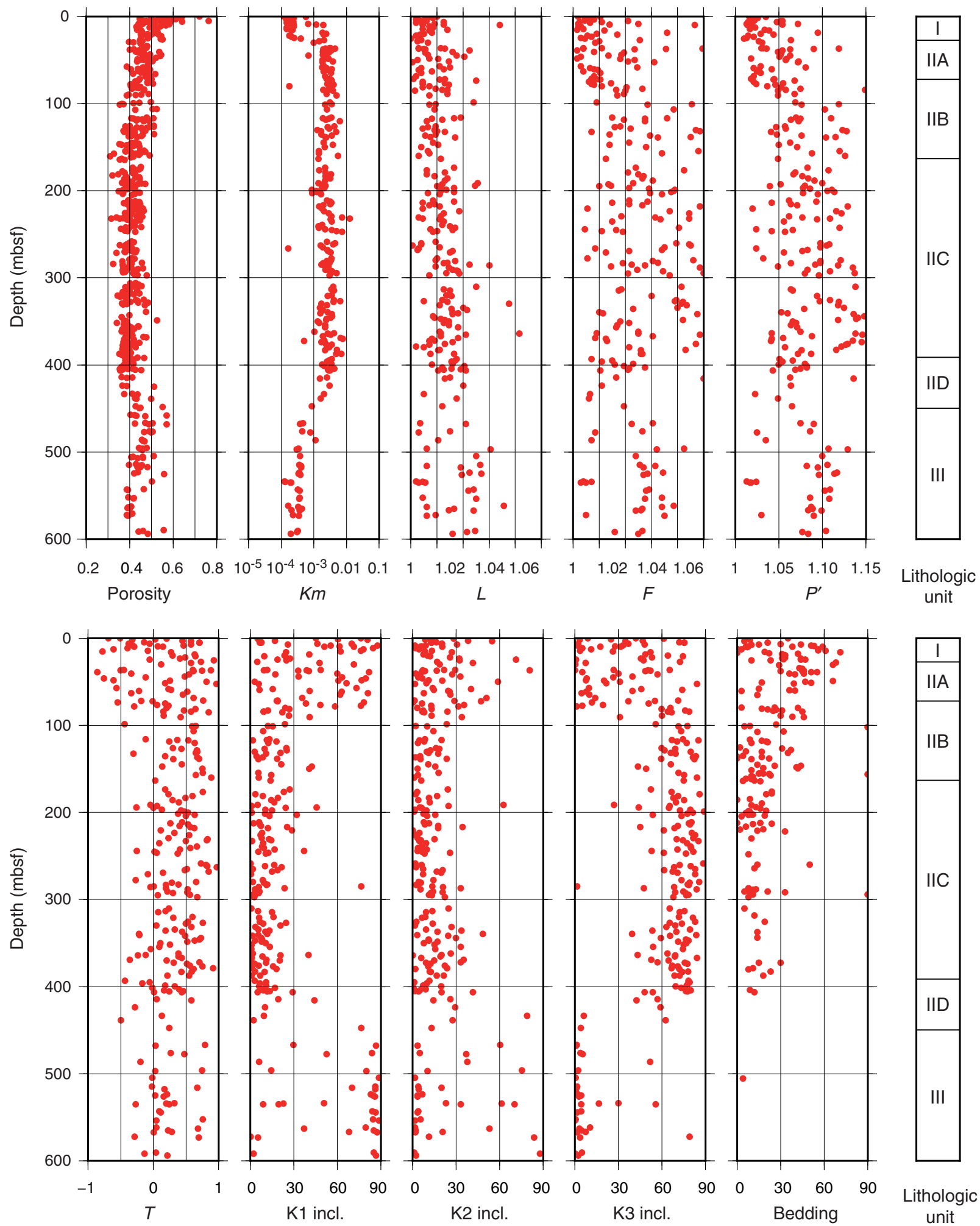

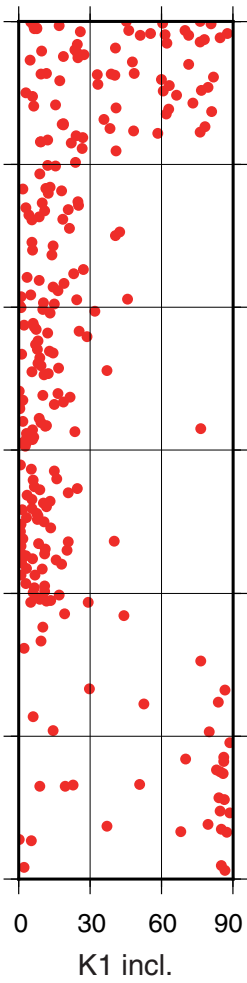

$\left({ }^{\circ}\right)$

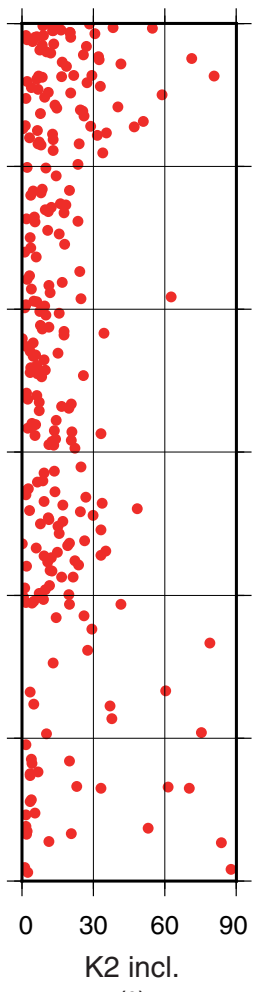

$\left({ }^{\circ}\right)$

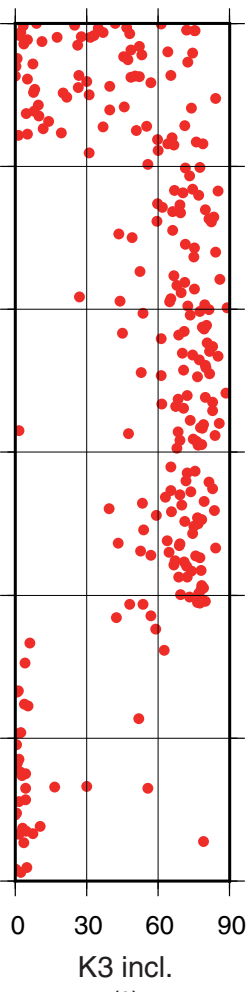

$\left({ }^{\circ}\right)$

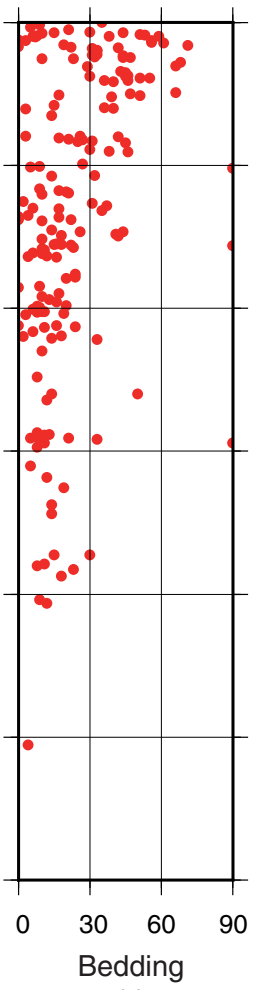

$\left({ }^{\circ}\right)$

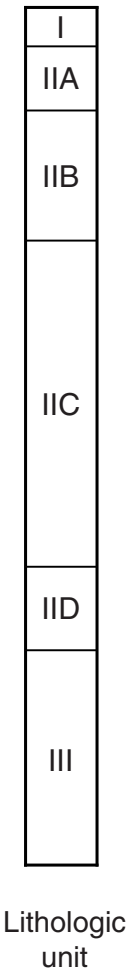

unit 
Figure F4. AMS parameters plotted against depth for samples from Site C0007. Porosity and bedding dip data are from onboard measurement (see the "Site C0007" chapter [Expedition 316 Scientists, 2009c]). Km = bulk magnetic susceptibility, $L=$ lineation parameter $(\mathrm{K} 1 / \mathrm{K} 3), F=$ flattening parameter $(\mathrm{K} 2 / \mathrm{K} 3), P^{\prime}=$ anisotropy degree, $T$ = shape parameter, incl. = inclination.

Site C0007
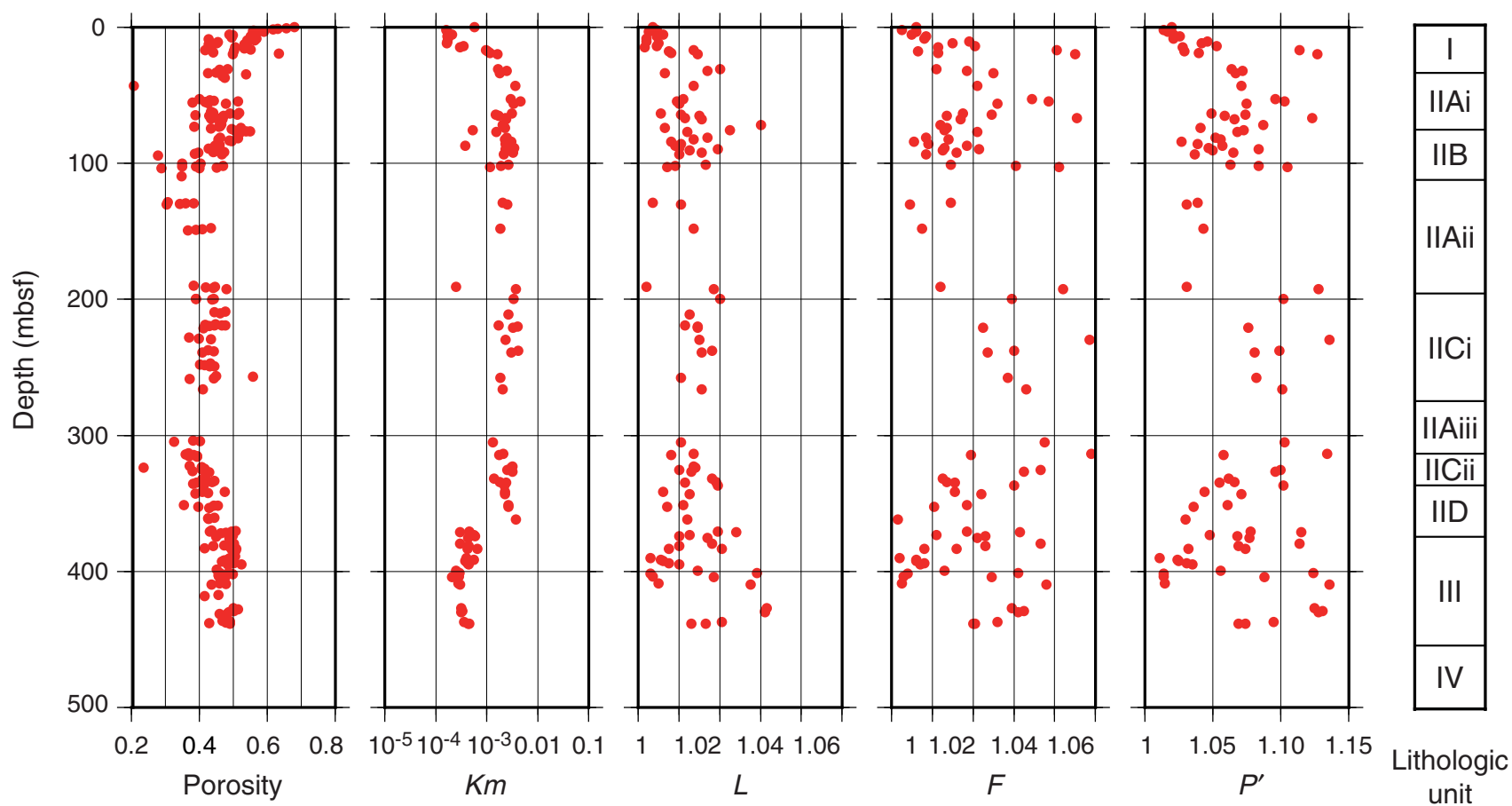

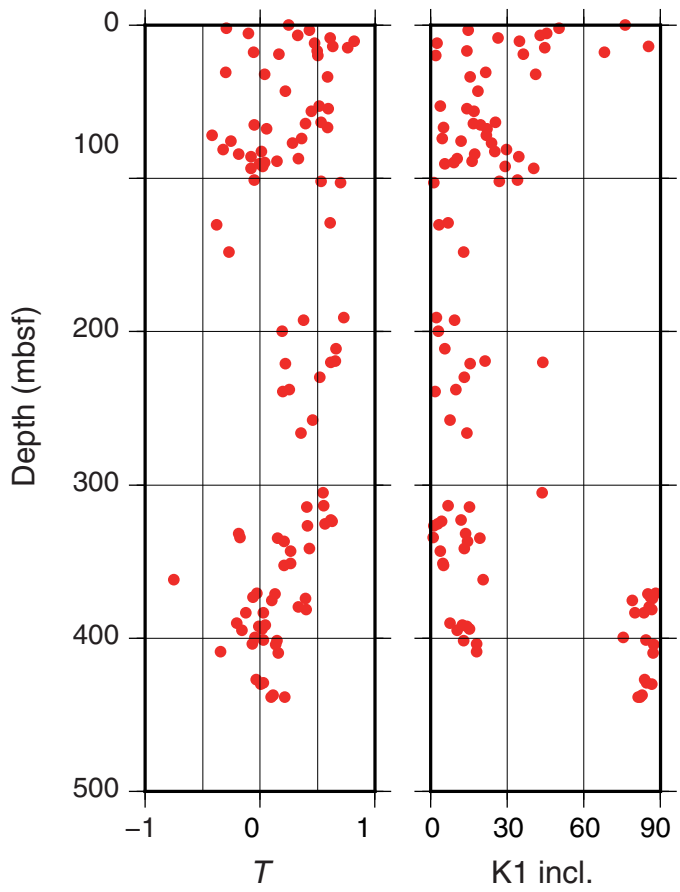

$\left({ }^{\circ}\right)$

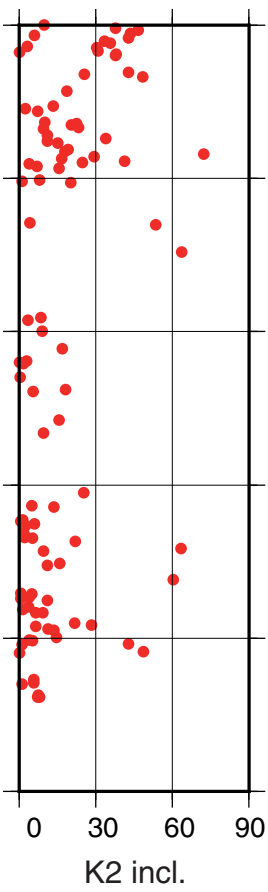

$\left({ }^{\circ}\right)$

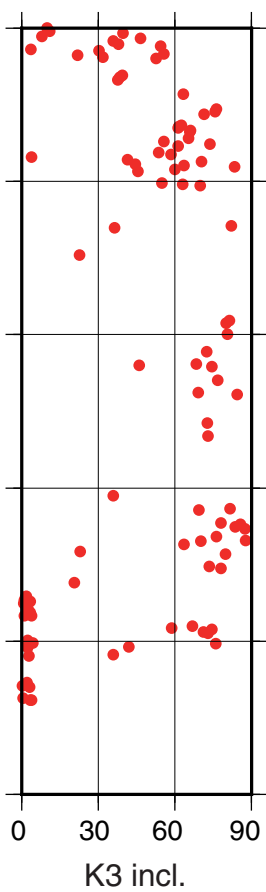

$\left({ }^{\circ}\right)$

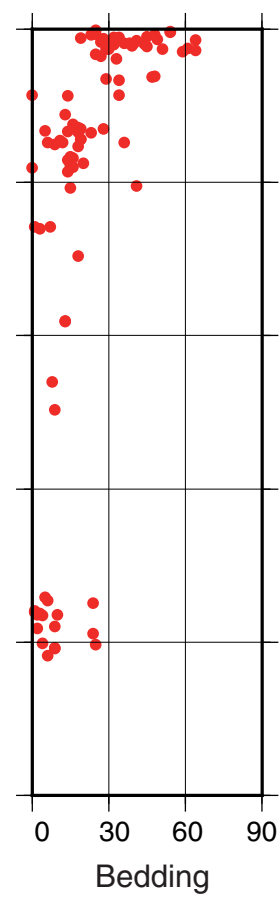

$\left({ }^{\circ}\right)$

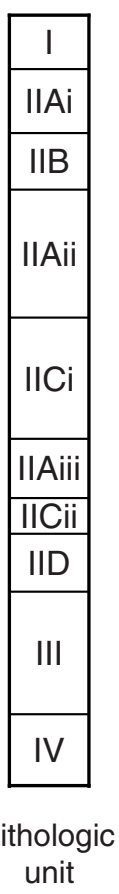

unit 
Figure F5. AMS parameters plotted against depth for samples from Site C0008. Porosity and bedding dip data are from onboard measurement (see the "Site C0008" chapter [Expedition 316 Scientists, 2009d]). Km = bulk magnetic susceptibility, $L=$ lineation parameter $(\mathrm{K} 1 / \mathrm{K} 3), F=$ flattening parameter $(\mathrm{K} 2 / \mathrm{K} 3), P^{\prime}=$ anisotropy degree, $T$ = shape parameter, incl. = inclination.

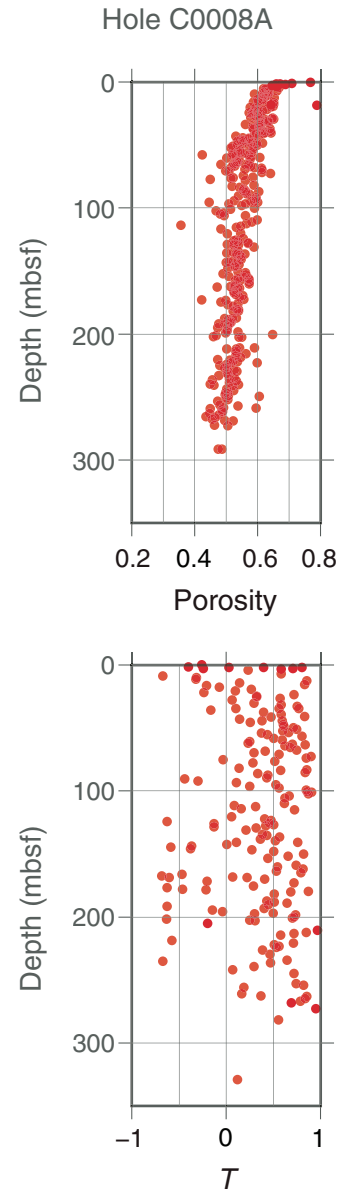

Hole C0008C
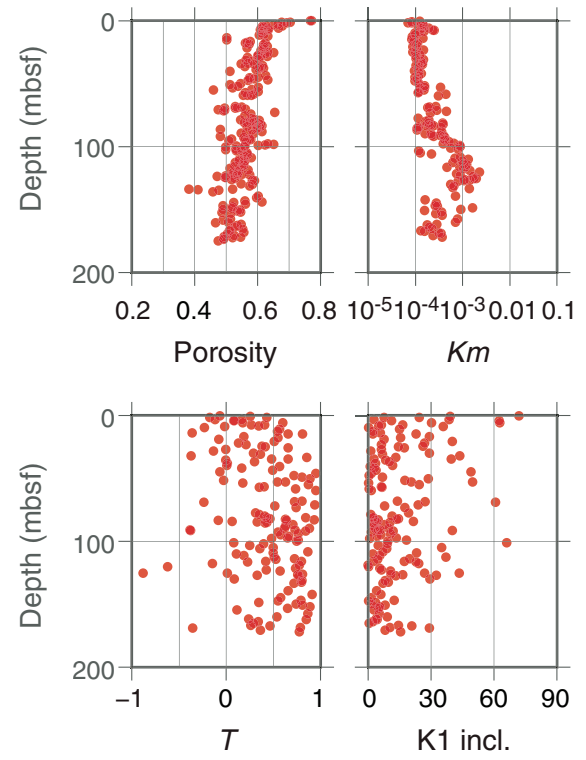

$\left({ }^{\circ}\right)$

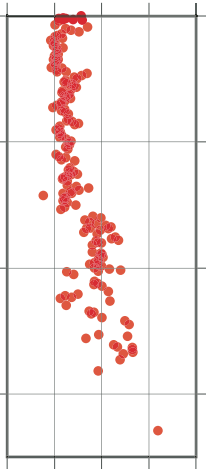

$\mathrm{Km}$

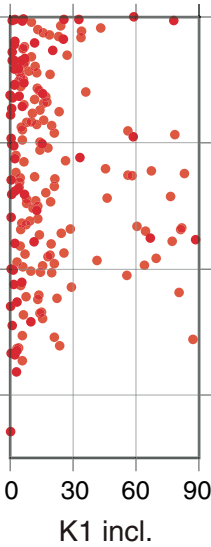

$\left({ }^{\circ}\right)$

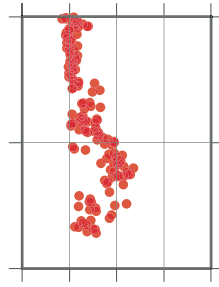

$\mathrm{Km}$

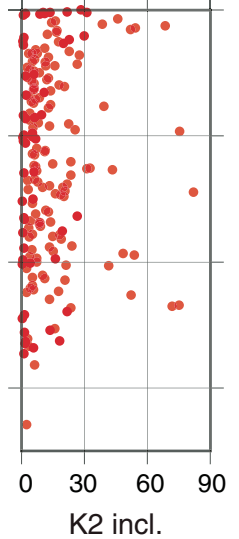

$\left({ }^{\circ}\right)$

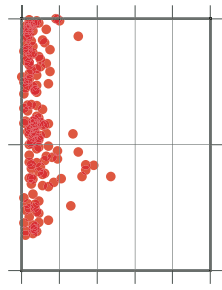

$L$

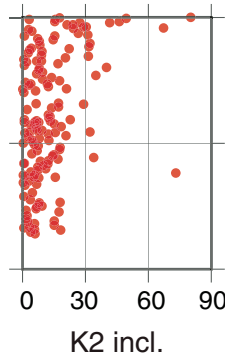

$\left(^{\circ}\right)$
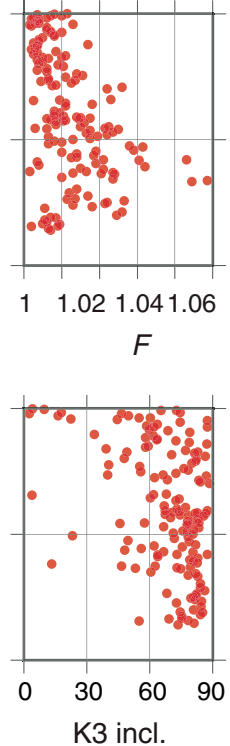

$\left({ }^{\circ}\right)$

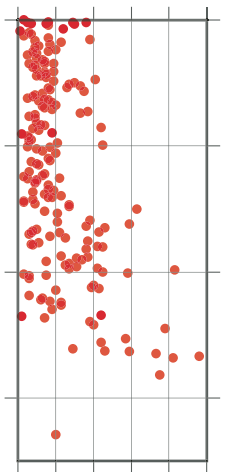

11.021 .041 .06

F

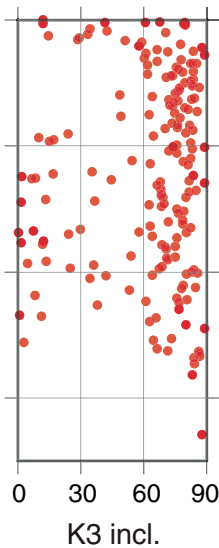

$\left({ }^{\circ}\right)$

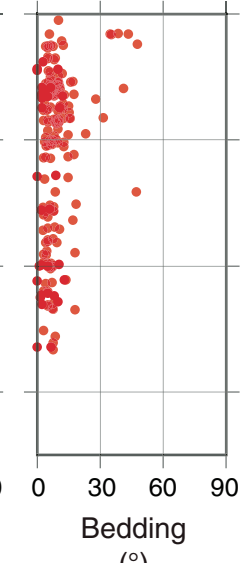

$\left({ }^{\circ}\right)$
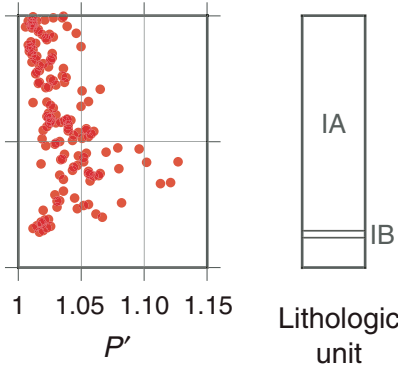

Lithologic unit

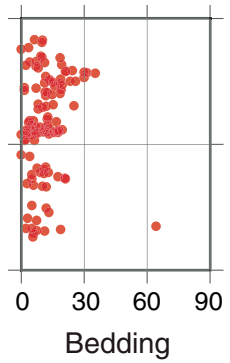

$\left(^{\circ}\right)$

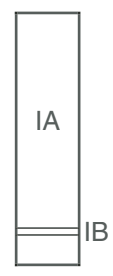

Lithologic unit 
Table T1. AMS measurements, Expedition 316.

\begin{tabular}{|c|c|c|c|c|c|c|c|c|c|c|c|c|c|c|c|c|c|c|c|c|c|}
\hline Core & Section & $\begin{array}{l}\text { Top } \\
\text { offset } \\
(\mathrm{cm})\end{array}$ & $\begin{array}{c}\text { Top } \\
\text { depth } \\
\text { (cm) }\end{array}$ & Unit & $\begin{array}{l}\text { Specimen } \\
\text { name }\end{array}$ & Km & K1 & K2 & K3 & $L$ & $F$ & $P$ & $P^{\prime}$ & $T$ & $q$ & $\begin{array}{c}\mathrm{K} 1 \mathrm{dec} \\
\left({ }^{\circ}\right)\end{array}$ & $\begin{array}{c}\mathrm{K} 1 \mathrm{inc} \\
\left({ }^{\circ}\right)\end{array}$ & $\begin{array}{c}\text { K2 dec } \\
\left({ }^{\circ}\right)\end{array}$ & $\begin{array}{c}\mathrm{K} 2 \text { inc } \\
\left({ }^{\circ}\right)\end{array}$ & $\begin{array}{c}\text { K3 dec } \\
\left({ }^{\circ}\right)\end{array}$ & $\begin{array}{c}\mathrm{K} 3 \mathrm{inc} \\
\left({ }^{\circ}\right)\end{array}$ \\
\hline \multicolumn{22}{|c|}{ 316-C0004C- } \\
\hline $1 \mathrm{H}$ & 1 & 35 & 0.350 & 1 & 1H1_35 & 7.47E-04 & $7.50 \mathrm{E}-04$ & 7.47E-04 & 7.44E-04 & 1.005 & 1.003 & 1.008 & 1.008 & -0.272 & 0.935 & 93.7 & 26.3 & 200.9 & 31 & 331.4 & 47.2 \\
\hline $1 \mathrm{H}$ & 2 & 46 & 1.875 & I & 1H2_46 & 7.47E-04 & $7.58 \mathrm{E}-04$ & $7.45 \mathrm{E}-04$ & $7.40 \mathrm{E}-04$ & 1.018 & 1.006 & 1.024 & 1.025 & -0.478 & 1.178 & 84.1 & 19.2 & 351.7 & 6.9 & 242.7 & 69.5 \\
\hline $1 \mathrm{H}$ & 4 & 45 & 3.285 & I & 1H4_45 & $2.05 \mathrm{E}-04$ & $2.11 \mathrm{E}-04$ & $2.06 \mathrm{E}-04$ & $2.00 \mathrm{E}-04$ & 1.024 & 1.031 & 1.056 & 1.056 & 0.129 & 0.567 & 255 & 70 & 100.6 & 18.2 & 8 & 8.1 \\
\hline $1 \mathrm{H}$ & 5 & 41 & 4.650 & I & 1H5_41 & $1.41 \mathrm{E}-04$ & $1.43 \mathrm{E}-04$ & $1.41 \mathrm{E}-04$ & $1.40 \mathrm{E}-04$ & 1.009 & 1.007 & 1.016 & 1.016 & -0.136 & 0.797 & 74.5 & 13.3 & 340.8 & 15.5 & 203.4 & 69.4 \\
\hline $1 \mathrm{H}$ & 7 & 4 & 5.690 & I & 1H7_4 & $1.89 \mathrm{E}-04$ & $1.89 \mathrm{E}-04$ & $1.89 \mathrm{E}-04$ & $1.88 \mathrm{E}-04$ & 1.002 & 1.008 & 1.01 & 1.011 & 0.555 & 0.252 & 69.9 & 20 & 162.7 & 7.7 & 272.7 & 68.5 \\
\hline $2 \mathrm{H}$ & 1 & 72 & 7.100 & I & 2H1_72 & $1.32 \mathrm{E}-04$ & $1.32 \mathrm{E}-04$ & $1.32 \mathrm{E}-04$ & $1.31 \mathrm{E}-04$ & 1.006 & 1.006 & 1.013 & 1.013 & 0.018 & 0.653 & 284.2 & 7.1 & 18.4 & 30.3 & 182.3 & 58.7 \\
\hline $2 \mathrm{H}$ & 2 & 63 & 8.417 & 1 & $2 \mathrm{H} 2 \_63$ & $9.17 \mathrm{E}-05$ & $9.21 \mathrm{E}-05$ & $9.18 \mathrm{E}-05$ & $9.14 \mathrm{E}-05$ & 1.003 & 1.004 & 1.008 & 1.008 & 0.14 & 0.549 & 320 & 5.7 & 229.9 & 0.9 & 130.8 & 84.2 \\
\hline $2 \mathrm{H}$ & 4 & 18 & 9.377 & I & $2 \mathrm{H} 4 \_18$ & $1.01 \mathrm{E}-04$ & $1.02 \mathrm{E}-04$ & $1.01 \mathrm{E}-04$ & $9.97 \mathrm{E}-05$ & 1.004 & 1.015 & 1.019 & 1.02 & 0.589 & 0.231 & 349.7 & 6.7 & 79.9 & 1.9 & 185.4 & 83.1 \\
\hline $2 \mathrm{H}$ & 5 & 78 & 11.413 & I & 2H5_78 & $1.15 \mathrm{E}-04$ & $1.16 \mathrm{E}-04$ & $1.15 \mathrm{E}-04$ & $1.14 \mathrm{E}-04$ & 1.01 & 1.01 & 1.02 & 1.02 & -0.004 & 0.674 & 122.6 & 1.3 & 212.6 & 1 & 341.2 & 88.4 \\
\hline $2 \mathrm{H}$ & 6 & 106 & 13.125 & I & 2H6_106 & $1.23 \mathrm{E}-04$ & $1.24 \mathrm{E}-04$ & $1.24 \mathrm{E}-04$ & $1.22 \mathrm{E}-04$ & 1.002 & 1.017 & 1.019 & 1.021 & 0.822 & 0.094 & 299.5 & 22.2 & 29.6 & 0.2 & 120.2 & 67.8 \\
\hline $2 \mathrm{H}$ & 8 & 50 & 13.990 & I & 2H8_50 & $1.09 \mathrm{E}-04$ & $1.09 \mathrm{E}-04$ & $1.09 \mathrm{E}-04$ & $1.08 \mathrm{E}-04$ & 1.001 & 1.015 & 1.016 & 1.018 & 0.846 & 0.081 & 262 & 3.2 & 352.5 & 7.9 & 150 & 81.5 \\
\hline $2 \mathrm{H}$ & 9 & 129 & 16.194 & I & 2H9_129 & $9.80 \mathrm{E}-05$ & $9.87 \mathrm{E}-05$ & $9.81 \mathrm{E}-05$ & $9.72 \mathrm{E}-05$ & 1.006 & 1.009 & 1.015 & 1.015 & 0.229 & 0.48 & 254.4 & 9 & 346.3 & 11.6 & 127.5 & 75.3 \\
\hline $3 \mathrm{H}$ & 1 & 112 & 17.00 & 1 & 3H1_112 & $8.22 \mathrm{E}-05$ & $8.28 \mathrm{E}-05$ & $8.22 \mathrm{E}-05$ & $8.16 \mathrm{E}-05$ & 1.007 & 1.008 & 1.015 & 1.015 & 0.023 & 0.65 & 176.6 & 2.1 & 86.4 & 5.4 & 287.8 & 84.2 \\
\hline $3 \mathrm{H}$ & 2 & 80 & 18.093 & I & $3 \mathrm{H} 2-80$ & $9.48 \mathrm{E}-05$ & $9.54 \mathrm{E}-05$ & $9.52 \mathrm{E}-05$ & $9.39 \mathrm{E}-05$ & 1.002 & 1.014 & 1.016 & 1.018 & 0.734 & 0.144 & 253.4 & 8.9 & 344.3 & 5.8 & 107.1 & 79.4 \\
\hline $3 \mathrm{H}$ & 3 & 19 & 18.668 & I & 3H3_19 & $9.65 \mathrm{E}-05$ & $9.71 \mathrm{E}-05$ & $9.67 \mathrm{E}-05$ & $9.57 \mathrm{E}-05$ & 1.004 & 1.01 & 1.014 & 1.015 & 0.459 & 0.315 & 349.4 & 12.7 & 258.5 & 4.2 & 150.3 & 76.6 \\
\hline $3 \mathrm{H}$ & 4 & 14 & 18.833 & I & 3H4_14 & $9.48 \mathrm{E}-05$ & $9.58 \mathrm{E}-05$ & $9.52 \mathrm{E}-05$ & $9.35 \mathrm{E}-05$ & 1.007 & 1.017 & 1.025 & 1.025 & 0.414 & 0.346 & 351.5 & 11.3 & 260.3 & 5.7 & 144.1 & 77.3 \\
\hline $3 \mathrm{H}$ & 6 & 83 & 20.948 & 1 & 3H6_83 & $8.03 \mathrm{E}-05$ & 8.07E-05 & $8.04 \mathrm{E}-05$ & $7.98 \mathrm{E}-05$ & 1.003 & 1.008 & 1.01 & 1.011 & 0.484 & 0.297 & 1.3 & 35 & 258.8 & 17.2 & 147.3 & 49.9 \\
\hline $3 \mathrm{H}$ & 7 & 42 & 21.973 & I & 3H7_42 & $8.40 \mathrm{E}-05$ & 8.47E-05 & $8.38 \mathrm{E}-05$ & $8.36 \mathrm{E}-05$ & 1.011 & 1.003 & 1.014 & 1.015 & -0.578 & 1.306 & 331.9 & 19.4 & 237.3 & 12.8 & 116 & 66.5 \\
\hline $3 \mathrm{H}$ & 9 & 32 & 23.298 & I & 3H9_32 & $9.07 \mathrm{E}-05$ & $9.23 \mathrm{E}-05$ & $9.10 \mathrm{E}-05$ & $8.89 \mathrm{E}-05$ & 1.015 & 1.023 & 1.038 & 1.039 & 0.224 & 0.488 & 310.4 & 4.3 & 40.6 & 2.9 & 164 & 84.8 \\
\hline $3 \mathrm{H}$ & 10 & 71 & 25.098 & 1 & 3H10_71 & $1.35 \mathrm{E}-04$ & $1.36 \mathrm{E}-04$ & $1.36 \mathrm{E}-04$ & $1.34 \mathrm{E}-04$ & 1.004 & 1.013 & 1.017 & 1.018 & 0.548 & 0.256 & 298.5 & 14.4 & 28.6 & 0.2 & 119.5 & 75.6 \\
\hline $4 \mathrm{H}$ & 1 & 15 & 25.530 & I & $4 \mathrm{H} 1 \_115$ & $9.63 \mathrm{E}-05$ & $9.71 \mathrm{E}-05$ & $9.65 \mathrm{E}-05$ & $9.53 \mathrm{E}-05$ & 1.006 & 1.012 & 1.018 & 1.019 & 0.346 & 0.394 & 344.2 & 4 & 253.5 & 10 & 95.9 & 79.2 \\
\hline $4 \mathrm{H}$ & 2 & 48 & 27.275 & 1 & $4 \mathrm{H} 2 \_48$ & $9.81 \mathrm{E}-05$ & $9.90 \mathrm{E}-05$ & $9.86 \mathrm{E}-05$ & $9.67 \mathrm{E}-05$ & 1.003 & 1.02 & 1.024 & 1.025 & 0.702 & 0.163 & 7.9 & 8.8 & 277.8 & 0.9 & 182 & 81.2 \\
\hline $4 \mathrm{H}$ & 3 & 42 & 28.635 & I & 4H3_42 & $1.06 \mathrm{E}-04$ & 1.07E-04 & $1.07 \mathrm{E}-04$ & $1.05 \mathrm{E}-04$ & 1.005 & 1.016 & 1.021 & 1.022 & 0.541 & 0.261 & 320.6 & 27.5 & 224.7 & 11.1 & 114.8 & 60 \\
\hline $4 \mathrm{H}$ & 5 & 42 & 30.045 & I & 4H5_42 & $1.02 \mathrm{E}-04$ & $1.03 \mathrm{E}-04$ & $1.03 \mathrm{E}-04$ & $1.01 \mathrm{E}-04$ & 1.002 & 1.016 & 1.017 & 1.019 & 0.801 & 0.105 & 181.3 & 0.4 & 271.3 & 3.7 & 84.6 & 86.3 \\
\hline $4 \mathrm{H}$ & 6 & 39 & 31.445 & 1 & 4H6_39 & $1.05 \mathrm{E}-04$ & $1.06 \mathrm{E}-04$ & $1.06 \mathrm{E}-04$ & $1.05 \mathrm{E}-04$ & 1.002 & 1.01 & 1.012 & 1.013 & 0.62 & 0.211 & 340.7 & 0.7 & 250.4 & 22.5 & 72.4 & 67.5 \\
\hline $4 \mathrm{H}$ & 7 & 71 & 33.205 & I & 4H7_71 & 1.07E-04 & $1.09 \mathrm{E}-04$ & $1.08 \mathrm{E}-04$ & $1.02 \mathrm{E}-04$ & 1.013 & 1.057 & 1.071 & 1.076 & 0.627 & 0.212 & 8.1 & 3.9 & 98.2 & 0.4 & 194.4 & 86.1 \\
\hline $4 \mathrm{H}$ & 8 & 45 & 34.365 & I & 4H8_45 & $8.54 \mathrm{E}-05$ & $8.61 \mathrm{E}-05$ & $8.60 \mathrm{E}-05$ & $8.43 \mathrm{E}-05$ & 1.001 & 1.02 & 1.021 & 1.024 & 0.89 & 0.057 & 318.7 & 1 & 48.9 & 12.8 & 224.2 & 77.2 \\
\hline $5 \mathrm{H}$ & 1 & 33 & 35.210 & I & $5 \mathrm{H} 1 \_33$ & $1.00 \mathrm{E}-04$ & $1.01 \mathrm{E}-04$ & $9.99 \mathrm{E}-05$ & $9.93 \mathrm{E}-05$ & 1.011 & 1.006 & 1.016 & 1.017 & -0.307 & 0.975 & 158.1 & 33.4 & 62.8 & 8 & 321.1 & 55.4 \\
\hline $5 \mathrm{H}$ & 2 & 122 & 37.535 & 1 & $5 \mathrm{H} 2-122$ & $1.05 \mathrm{E}-04$ & $1.06 \mathrm{E}-04$ & $1.06 \mathrm{E}-04$ & $1.01 \mathrm{E}-04$ & 1.005 & 1.043 & 1.048 & 1.053 & 0.8 & 0.108 & 339.7 & 5 & 70.6 & 10.1 & 224 & 78.7 \\
\hline $5 \mathrm{H}$ & 3 & 47 & 38.280 & I & $5 \mathrm{H} 3 \_47$ & $9.89 \mathrm{E}-05$ & 9.97E-05 & $9.90 \mathrm{E}-05$ & $9.80 \mathrm{E}-05$ & 1.006 & 1.011 & 1.017 & 1.017 & 0.259 & 0.458 & 107.3 & 18 & 199.6 & 7 & 309.9 & 70.6 \\
\hline $5 \mathrm{H}$ & 5 & 44 & 39.720 & I & 5H5_44 & $7.92 \mathrm{E}-05$ & $8.01 \mathrm{E}-05$ & $7.94 \mathrm{E}-05$ & $7.81 \mathrm{E}-05$ & 1.009 & 1.017 & 1.026 & 1.026 & 0.299 & 0.429 & 330.1 & 0.1 & 240 & 13.6 & 60.4 & 76.4 \\
\hline $5 \mathrm{H}$ & 6 & 52 & 41.305 & I & $5 \mathrm{H} 6 \_52$ & $9.84 \mathrm{E}-05$ & $9.95 \mathrm{E}-05$ & $9.89 \mathrm{E}-05$ & $9.67 \mathrm{E}-05$ & 1.006 & 1.023 & 1.029 & 1.03 & 0.569 & 0.245 & 133.1 & 18.1 & 228.8 & 16.7 & 358.7 & 65 \\
\hline $5 \mathrm{H}$ & 7 & 32 & 42.560 & 1 & 5H7_32 & $1.06 \mathrm{E}-04$ & $1.07 \mathrm{E}-04$ & $1.06 \mathrm{E}-04$ & $1.05 \mathrm{E}-04$ & 1.005 & 1.01 & 1.015 & 1.015 & 0.341 & 0.397 & 85.6 & 3.2 & 355.4 & 2.5 & 227.4 & 86 \\
\hline $5 \mathrm{H}$ & 8 & 74 & 44.385 & I & $5 \mathrm{H} 8 \_74$ & $1.18 \mathrm{E}-04$ & $1.19 \mathrm{E}-04$ & $1.18 \mathrm{E}-04$ & $1.17 \mathrm{E}-04$ & 1.008 & 1.011 & 1.019 & 1.019 & 0.199 & 0.505 & 130.5 & 13.7 & 222.3 & 7.6 & 340.5 & 74.3 \\
\hline $6 \mathrm{H}$ & 1 & 35 & 44.730 & I & 6H1_36 & $9.56 \mathrm{E}-05$ & $9.62 \mathrm{E}-05$ & $9.59 \mathrm{E}-05$ & $9.47 \mathrm{E}-05$ & 1.003 & 1.012 & 1.015 & 1.016 & 0.549 & 0.256 & 77.3 & 10.9 & 168.9 & 8.2 & 295 & 76.3 \\
\hline $6 \mathrm{H}$ & 2 & 37 & 46.175 & 1 & $6 \mathrm{H} 2 \_37$ & $9.53 \mathrm{E}-05$ & $9.59 \mathrm{E}-05$ & $9.56 \mathrm{E}-05$ & $9.44 \mathrm{E}-05$ & 1.004 & 1.013 & 1.017 & 1.018 & 0.502 & 0.286 & 306 & 8.4 & 213.5 & 16.2 & 62.4 & 71.7 \\
\hline $6 \mathrm{H}$ & 3 & 39 & 47.640 & I & $6 \mathrm{H}_{3} \_39$ & $7.99 \mathrm{E}-05$ & $8.11 \mathrm{E}-05$ & $8.07 \mathrm{E}-05$ & $7.79 \mathrm{E}-05$ & 1.005 & 1.037 & 1.041 & 1.045 & 0.772 & 0.123 & 69.8 & 0.1 & 159.8 & 1.9 & 336.6 & 88.1 \\
\hline $6 \mathrm{H}$ & 5 & 52 & 49.210 & 1 & 6H5_52 & $9.99 \mathrm{E}-05$ & $1.01 \mathrm{E}-04$ & $1.00 \mathrm{E}-04$ & $9.88 \mathrm{E}-05$ & 1.005 & 1.015 & 1.02 & 1.021 & 0.535 & 0.265 & 58.4 & 7.2 & 328.3 & 1.4 & 227 & 82.6 \\
\hline $6 \mathrm{H}$ & 6 & 54 & 50.685 & 1 & $6 \mathrm{H} 6 \_53$ & $1.09 \mathrm{E}-04$ & $1.10 \mathrm{E}-04$ & $1.09 \mathrm{E}-04$ & $1.07 \mathrm{E}-04$ & 1.004 & 1.023 & 1.026 & 1.029 & 0.73 & 0.147 & 154.7 & 9 & 244.8 & 0.8 & 340.1 & 81 \\
\hline $6 \mathrm{H}$ & 7 & 80 & 52.405 & I & 6H7_-80 & 1.19E-04 & $1.20 \mathrm{E}-04$ & $1.19 \mathrm{E}-04$ & $1.18 \mathrm{E}-04$ & 1.005 & 1.009 & 1.014 & 1.014 & 0.241 & 0.471 & 54.1 & 5.1 & 147.8 & 36 & 317.2 & 53.5 \\
\hline $6 \mathrm{H}$ & 8 & 71 & 53.825 & 1 & 6H8_71 & $1.11 \mathrm{E}-04$ & $1.12 \mathrm{E}-04$ & $1.12 \mathrm{E}-04$ & $1.10 \mathrm{E}-04$ & 1.003 & 1.02 & 1.024 & 1.025 & 0.718 & 0.153 & 177.7 & 1.3 & 87.3 & 18.8 & 271.5 & 71.1 \\
\hline $7 \mathrm{H}$ & 1 & 123 & 55.110 & 1 & 7H1_123 & $1.24 \mathrm{E}-04$ & $1.26 \mathrm{E}-04$ & $1.24 \mathrm{E}-04$ & $1.22 \mathrm{E}-04$ & 1.018 & 1.016 & 1.033 & 1.033 & -0.06 & 0.729 & 304.7 & 0.9 & 38 & 73.9 & 214.4 & 16.1 \\
\hline $7 \mathrm{H}$ & 2 & 30 & 55.597 & I & 7H2_30 & $1.41 \mathrm{E}-04$ & $1.43 \mathrm{E}-04$ & $1.41 \mathrm{E}-04$ & $1.39 \mathrm{E}-04$ & 1.015 & 1.017 & 1.032 & 1.032 & 0.07 & 0.613 & 281.9 & 3 & 191.3 & 11.5 & 26.1 & 78.1 \\
\hline $7 \mathrm{H}$ & 3 & 19 & 56.917 & I & 7H3_19 & $1.48 \mathrm{E}-04$ & $1.50 \mathrm{E}-04$ & $1.47 \mathrm{E}-04$ & $1.47 \mathrm{E}-04$ & 1.016 & 1.003 & 1.019 & 1.021 & -0.672 & 1.44 & 95.8 & 14.3 & 341 & 58.7 & 193.3 & 27.2 \\
\hline $7 \mathrm{H}$ & 4 & 9 & 58.014 & I & 7H4_9 & $2.34 \mathrm{E}-04$ & $2.36 \mathrm{E}-04$ & $2.35 \mathrm{E}-04$ & $2.32 \mathrm{E}-04$ & 1.004 & 1.013 & 1.017 & 1.018 & 0.533 & 0.267 & 99.6 & 11.2 & 189.7 & 0.5 & 282.3 & 78.8 \\
\hline $7 \mathrm{H}$ & 5 & 30 & 58.439 & I & 7H5_30 & $1.45 \mathrm{E}-04$ & 1.47E-04 & $1.46 \mathrm{E}-04$ & $1.44 \mathrm{E}-04$ & 1.009 & 1.011 & 1.02 & 1.02 & 0.105 & 0.581 & 105.4 & 4.8 & 195.5 & 0.6 & 293.2 & 85.2 \\
\hline
\end{tabular}




\section{Appendix}

Below is the list of AMS parameters used in Table T1 and their mathematical expression.

$$
\begin{aligned}
& K m=\text { bulk magnetic susceptibility; }(|\mathrm{K} 1|+|\mathrm{K} 2|+ \\
& \qquad|\mathrm{K} 3|) / 3 \text { SI. }
\end{aligned}
$$

$\mathrm{K} 1, \mathrm{~K} 2, \mathrm{~K} 3=$ principal normed susceptibilities $(\mathrm{K} 1>$

$$
\mathrm{K} 2>\mathrm{K} 3 \text { ), }
$$

where $n 1, n 2$ and $n 3$ are their respective natural logarithms.

$$
\begin{gathered}
L=\mathrm{K} 1 / \mathrm{K} 2 \\
F=\mathrm{K} 2 / \mathrm{K} 3 \\
P=\mathrm{K} 1 / \mathrm{K} 3 \\
P^{\prime}=\exp \sqrt{2\left\{(n 1-n)^{2}+(n 2-n)^{2}+(n 3-n)^{2}\right\}} \\
T=(2 n 2-n 1-n 3) /(n 1-n 3) \\
q=(\mathrm{K} 1-\mathrm{K} 2) /\{(\mathrm{K} 1+\mathrm{K} 2) / 2-\mathrm{K} 3\}
\end{gathered}
$$

$\mathrm{K} 1 \mathrm{dec}=$ declination of $\mathrm{K} 1$ in core coordinate system

$\mathrm{K} 1 \mathrm{inc}=$ inclination of $\mathrm{K} 1$ in core coordinate system

$\mathrm{K} 2 \mathrm{dec}=$ declination of $\mathrm{K} 2$ in core coordinate system

$\mathrm{K} 2$ inc = inclination of $\mathrm{K} 2$ in core coordinate system

$\mathrm{K} 3 \mathrm{dec}=$ declination of $\mathrm{K} 3$ in core coordinate system

$\mathrm{K} 3$ inc $=$ inclination of $\mathrm{K} 3$ in core coordinate system 